\title{
Basic Investigation of High-efficiency Power Control between Frequency-controlled Inverter Power Supply and Spot Welding Load
}

\author{
Y. Takasaki, and T. Sonoda* \\ Department of Information and Systems Engineering, Faculty of Information Engineering, Fukuoka Institute of Technology, \\ 3-30-1 Wajiro-Higashi, Higashiku, Fukuoka 811-0295, Japan
}

*School of Humanity-Oriented Science and Engineering, Department of Electrical and Communication Engineering, Kinki Univ., 11-6 Kayanomori, Iizuka 820-8555, Japan

\begin{abstract}
We developed a frequency-controlled inverter power supply for spot welding machines. The welding currents reached $10 \mathrm{kA}$ or higher, while impedance at the weld was extremely small, at $1 \mathrm{~m} \Omega$ or less. These conditions demanded welding power supplies capable of providing low voltage at high current. To develop such a power supply, we investigated how to control the welding current using an inverter power supply by installing an internal transformer with a large winding ratio. However, due to issues concerning the global environment and energy conservation, inverter power supplies require increasingly higher efficiency. One method of improving efficiency is to match the impedance between the inverter power supply and the load. The leakage impedance of the inverter transformer, however, is dependent on frequency and current. In addition, the extremely low load ( $1 \mathrm{~m} \Omega$ or less) makes such impedance matching difficult to implement. This paper presents the results of an investigation into high-efficiency power control between an inverter power supply with an internal transformer (with a large winding ratio) and a load of no more than $1 \mathrm{~m} \Omega$. The results confirmed that inverter output power that maximized frequency and matching were possible.
\end{abstract}

Key words: Spot welding machine, inverter power supply, transformer constants, spot welding load, impedance matching

\section{周波数制御形インバータ電源によるスポット溶接負荷 への高効率電力供給に関する基礎的検討}

\author{
高㟝佳明・園田敏勝* \\ 福岡工業大学情報工学部情報システム工学科, 福岡市東区和白東 3-30-1（テ811-0295） \\ “近畿大学産業理工学部電気通信工学科, 飯塚市柏の森 11-6（广820-8555）
}

\section{1. はじめに}

本論文は，巻数比の大きい変圧器を内蔵する周波数制御

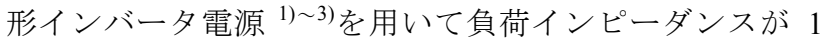
$[\mathrm{m} \Omega]$ 以下を想定したスポット溶接電力の振舞について検 討したものである，具体的には，(1)インバータ電源と負荷 とのインピーダンスマッチングに対する基礎的検討，(2)電 源周波数に対する負荷力率，(3)電源周波数と負荷電力との 関係である.

今日, 自動車工業, 家電, 製缶業界などではスポット溶 接機が多用されており 4) 7)，その容量が50〔kVA〕を超え ると，高圧受電設備を必要とする。したがって，小規模工 場や大容量電源の得られない建設現場などでは，携帯用ス ポット溶接機の開発が求められていた ${ }^{4)}$. これに対し, 筆 者らは家庭に供給されている商用電源(100〔V〕，20〔A〕） で動作する磁束制御形スポット溶接機の開発を行い 8) 10), 続いて低電圧大電流負荷に適する巻数比の大きい変圧器を 内蔵するインバータ電源の開発を行ってきた ${ }^{1) ~ 3) . ~}$

たとえば，スポット溶接機を用いて鉄板同士を溶接する 場合, 溶接回路の等価溶接抵抗は, 溶接部の温度上昇に伴
い, 数倍は変化する場合がある 10)。さらに, 要求される電

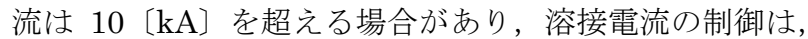
簡単でないことを経験した ${ }^{10)}$ 。筆者らは，この問題の解決 を目指し，インバータの周波数を制御する方式のインバー 夕電源を提案して，溶接電流の制御を可能にした 1 ).

また，周波数制御形インバータ電源の方式は，今日，誘 導機の可変速運転やモータドライブなどで広く用いられて いる PWM 方式 11) と異なり, 直流電源を変圧器の 1 次巻線 に正負交互に切り替えて入力 (矩形波) 寸る簡単な方式で ある。したがって，取り扱う電流は，非正弦波の交流で数 千アンペアとなるため, これまでに電流制御に対する適切 な指針を与える論文等の資料は見当たらない.

一方，近年では，省エネ，地球環境の観点からインバー 夕電源の高効率化が望まれ，インバータに用いるスイッチ ング素子の改良開発が顕著である 12) 15)。周知のように高 効率化を実現する一つの方法は, インバータ電源と負荷で ある溶接部とのインピーダンスマッチングを行うことであ る.つまり, 如何にして, 溶接部に高効率で電力を送り込 むかが大きな課題となる. しかしながら，巻数比の大きい 変圧器を内蔵するインバータ電源と $1[\mathrm{~m} \Omega]$ 以下を想定し 
た負荷とのインピーダンスマッチングを実現するのは簡単 でなく,インピーダンスマッチング問題に対す指針を得る 必要がある。

本論文は，この指針を得るため，まず，変圧器を内蔵し ていない電子回路で構成するインバータ電源を用いて，イ ンピーダンスマッチングの問題について検討した。 その結 果, 電源と負荷とがともに抵抗成分のみであれば, 理論と 実験とは一致し，正弦波，矩形波いずれの場合でも，電源 の内部抵抗と負荷抵抗の大きさとが等しい時，負荷電力は 最大になることを確認した. 次に, 同じインバータ電源で, 電源と負荷とがともに抵抗と誘導成分を有する場合には, 正弦波，矩形波いずれの場合でも負荷電力を最大とする負 荷抵抗の存在することを確認した．そして，巻数比の大き い変圧器を内蔵するインバータ電源を用いた場合には, 正 弦波，矩形波いずれの場合でも，変圧器の 1 次巻線に供給 する負荷力率が最大となる周波数の存在することを確認し， 電源周波数に対する負荷電力の振舞について確認した。

以上の検討結果より, 目指寸巻数比の大きい変圧器を内 蔵する周波数制御形インバータ電源を用いてスポット溶接 部に高効率で電力を供給する際の指針を得ることができ た.

\section{2. インバータ電源と負荷とのインピーダンスマッチング}

ここでは，インバータ電源と電源に繋がる負荷とのイン ピーダンスマッチングの問題について検討する．まず，電 源に変圧器を内蔵しない場合には, 変圧器定数の周波数・ 電源電圧・電流依存性を考える必要がないことから理論と 実験とは, 一致すると考えられる。 しかしながら, 変圧器 を内蔵する場合には, 変圧器定数が絡みマッチング問題は, 簡単には議論できないと考えられる。

\section{1 変圧器を内蔵しないインバータ電源}

Fig. 1 は, 変圧器を内蔵しない電子回路で構成するイン バータ電源とその負荷である溶接部とのインピーダンスマ ッチングの基礎について検討するために構成した実験回路 である. 正確な実験結果を得るため, インバータ電源 $\dot{V}_{\mathrm{S}}$ は, 任意波形発生器 F.G.とアナログ電力増幅器 P.A. とを用いて 構成している. 負荷電力 $P_{\mathrm{L}}$ は, デジタル型の電力計 P.M. を用いて $P_{\text {det }}$ して計測する. なお，P.M.の計測精度につ いては, 電流力計型電力計の測定値と比較した. その結果, 正弦波, 矩形波 $15 \sim 130[\mathrm{~Hz}], 0.5 \sim 5[\mathrm{~A}(\mathrm{rms})], 8[\mathrm{~W}(\mathrm{rms})]$ 以上に対して，両電力計の計測差は $5[\%]$ 以内であった 16).

変圧器を内蔵しないインバータ電源のインピーダンス $\dot{Z}_{\mathrm{S}}$ を(1)式，負荷インピーダンス $\dot{Z}_{\mathrm{L}}$ (2)式とする.

$$
\dot{Z}_{S}=r_{S}+j x_{S}
$$

$$
\dot{Z}_{L}=R_{L}+j X_{L}
$$

正弦波交流電源において $P_{\mathrm{L}}$ を最大とする条件は, 周知の ように(3), (4)式より (5), (6)式で与えられ, 最大負荷電力 $P_{\max }$ は(7)式となる ${ }^{16) \sim 18)}$. (5)式は, 電源と負荷インピーダ ンスそれぞれの虚数部が相殺した形になっており，(7)式は 直流回路における最大負荷電力の条件と一致する.

$$
\begin{aligned}
& \frac{\partial f\left(R_{L}, X_{L}\right)}{\partial R_{L}}=0, \quad \frac{\partial f\left(R_{L}, X_{L}\right)}{\partial X_{L}}=0 \\
& \frac{\partial^{2} f\left(R_{L}, X_{L}\right)}{\partial R_{L}^{2}} \frac{\partial^{2} f\left(R_{L}, X_{L}\right)}{\partial X_{L}^{2}}-\left(\frac{\partial^{2} f\left(R_{L}, X_{L}\right)}{\partial R_{L} \partial X_{L}}\right)^{2}>0, \quad \frac{\partial^{2} f\left(R_{L}, X_{L}\right)}{\partial R_{L}^{2}}>0 \\
& x_{S}=-X_{L}
\end{aligned}
$$

$$
\begin{aligned}
& r_{S}=R_{L} \\
& P_{\max }=\frac{\left|\dot{V}_{S}\right|^{2}}{4 r_{S}}=\frac{\left|\dot{V}_{S}\right|^{2}}{4 R_{L}}
\end{aligned}
$$

\section{2 実験結果（変圧器を内蔵しないインバータ電源）}

ここでは, まず正弦波の場合で $P_{\mathrm{L}}$ を最大とする条件と実 験結果とが一致するかどうかを確認する. 実験に用いる $x \mathrm{~S}$ と $X_{\mathrm{L}}$ の両リアクタンスには, 鉄の非線形性と鉄損の影響を 無くすために空心コイルを用いることにする.

Fig. 2 は, Fig. 1 の実験回路でインバータ電源を正弦波 交流, 周波数 $f_{\mathrm{S}}$ を $100[\mathrm{~Hz}]$ とし, $\dot{Z}_{\mathrm{S}}=r_{\mathrm{S}}+j 0, \quad \dot{Z}_{\mathrm{L}}=R_{\mathrm{L}}+j 0$ として $R_{\mathrm{L}}$ を変化した場合の $P$ 而振舞いを示したものであ る. Fig. 2 の下部には， $V_{\mathrm{S}}, f_{\mathrm{S}}$ などの実験条件を示している. $P_{\mathrm{L}}$ は, $r_{\mathrm{S}}=0.67[\Omega]$ に対し， $\left.R_{\mathrm{L}}=0.69 〔 \Omega\right]$ で最大となり $3[\%] の$ 誤差を許すと理論と実験結果とは一致している. また，(7)式の $P_{\max }$ が最大となる計算值 $P_{\text {max,Cal }}$ と測定值 $P_{\max , \mathrm{Ex}}$ は，それぞれ $6.52 〔 \mathrm{~W} 〕 ， 6.35 〔 \mathrm{~W} 〕$ となり，両值 の差は $3[\%]$ 程度である.

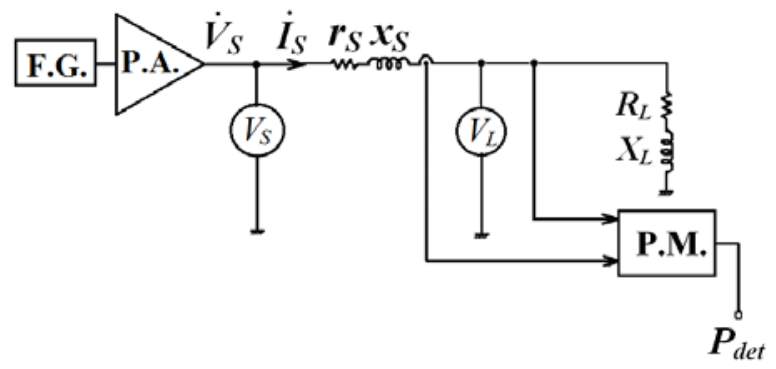

F.G.: Function generator, P.A.: Power amplifier, $\dot{V}_{\mathrm{S}}$ : Inverter power supply voltage, $V_{\mathrm{S}}$ : Inverter power supply voltage $(\mathrm{rms}), \dot{I}_{\mathrm{S}}$ : Inverter power supply current, $r_{\mathrm{S}}$ : Source resistance, $x_{\mathrm{S}}$ : Source reactance, $V_{\mathrm{L}}$ : Load voltage $(\mathrm{rms}), R_{\mathrm{L}}$ : Load resistance, $X_{\mathrm{L}}$ : Load reactance, P.M.: Digital power meter, $P_{\text {det }}$ : Measured value of $P_{\mathrm{L}}$.

Fig. 1 Experimental circuit for impedance matching without transformer.

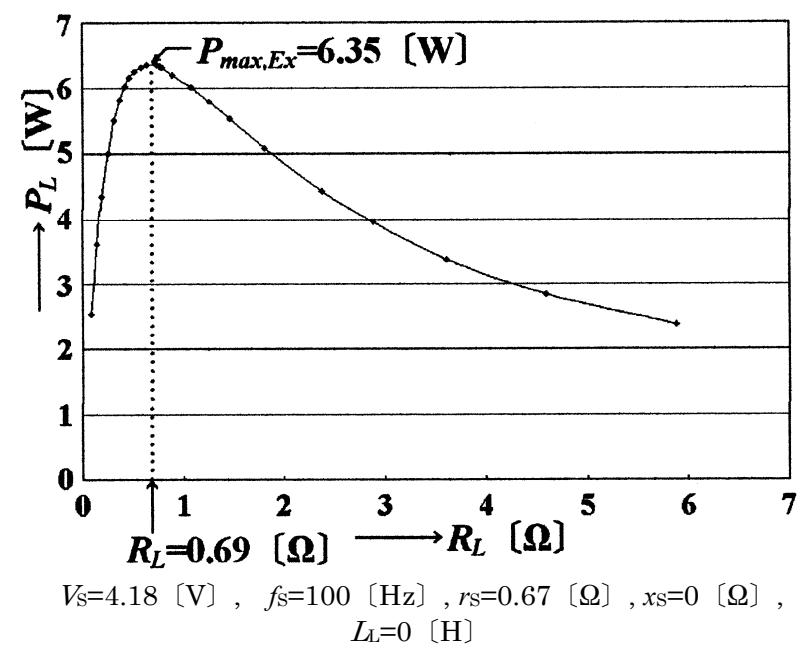

Fig. 2 Behavior of $P_{\mathrm{L}}$ with varying $R_{\mathrm{L}}$ (sine wave). 
Fig. 3 は, Fig. 1 の実験回路でインバータ電源を矩形波 とした場合であり，図の下部には， $V_{\mathrm{S}}, f_{\mathrm{S}}$ などの実験条件 を示している.ここで用いた矩形波は，Fig. 1 に示す P.M. と電流力計形電力計の測定值を比較した時と同様に, スル ーレートは $60[\mathrm{~V} / \mu \mathrm{s}]$ である. $r \mathrm{~s}=0.72[\Omega]$ に対し, $R_{\mathrm{L}}=0.71$

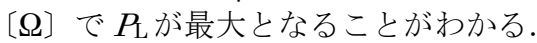

Fig. 2, Fig. 3 の結果は, 電源と負荷がともに抵抗成分の みであれば，正弦波，矩形波いずれの場合でも，電源の内 部抵抗と負荷抵抗の大きさとが等しい時に負荷電力は最大 になると言える。

Fig. 4 は, Fig. 1 の実験回路で $\dot{Z}_{\mathrm{S}}=r_{\mathrm{S}}+j x_{\mathrm{S}}, \dot{Z}_{\mathrm{L}}=R_{\mathrm{L}}+j X_{\mathrm{L}}$ とな るように回路を構成し，Fig. 2, Fig. 3 の場合と同様に $R$ L を変化した場合のP P を測定したものである．なお，Fig. 4 の下部には， $V_{\mathrm{S}}, f_{\mathrm{S}}$ などの実験条件を示しており， $x \mathrm{~S}$ と $X_{\mathrm{L}}$ の值は, $f_{\mathrm{S}}=100[\mathrm{~Hz}]$ の場合の值である.

Fig. 4 に示寸 $P_{\sin }$ は，電源波形が正弦波の場合で， $P_{\mathrm{sq}}$ は 矩形波の場合である. 両電源波形で $P_{\mathrm{L}}$ が最大となる電力を 比較すると $P_{\mathrm{sq}}$ が $P_{\mathrm{sin}}$ より $17[\%]$ 程度小さくなっている.

この差の原因は，矩形波の高調波成分に基づいて生じてい る. Fig. 4 の結果より, 正弦波, 矩形波いずれの場合も $P_{\mathrm{L}}$ を最大とする $R_{\mathrm{L}}$ の存在することが確認できる.

ここで， $P_{\sin }$ が最大となる $R_{\mathrm{L}}$ を求めると，3.54〔 $\Omega 〕$ と なるのに対して，実験值は概ね $3.9[\Omega] て ゙ あ り ， 10 〔 \%]$ 程度の誤差が生じている。この原因は測定誤差, 実験に用 いた空心コイルのインダクタンス測定誤差に基づくと考え ている.

\section{3 変圧器を内蔵するインバータ電源}

次に，検討するスポット溶接機の負荷は，低電圧大電流 負荷であることからインバータに巻数比の大きい変圧器を 繋いだ場合のマッチングについて検討する。つまり, 変圧 器を内蔵する電源を用いてインピーダンスが $1[\mathrm{~m} \Omega]$ 以下 を想定した負荷に電力を供給する場合でもマッチングが得 られるかどうかを確認する。

Fig. 5 は, Fig. 1 の $R_{\mathrm{L}}, X_{\mathrm{L}}$ 部に Table 1 に示す巻数比 $a\left(=N_{1} / N_{2}\right)$ が 40 である変圧器を繋いだ実験回路である. な お, Table 1 は, 文献”20）"に示すTable 1 を引用している.

Fig. 6 は, 試作した変圧器の外観である ${ }^{20)}$. スポット溶 接機の溶接電流は, $10[\mathrm{kA}]$ 以上に達する大電流になるこ とを考え, 変圧器の 2 次巻線 $N_{2}$ は, $780\left[\mathrm{~mm}^{2}\right]$ の断面積 を有する平角銅線を 1 turn としている。 その構造は，内鉄 型の両脚に施した 1 次巻線 $N_{1, \mathrm{p}}, N_{1, \mathrm{n}}$ の上に各 1 turn を巻 きつけて並列接続している. 2 次巻線端末部のひれ状に伸 びている部分は, 放熱を兼ねている. $N_{\text {sch }}$ は探りコイルで, 鉄心の磁束密度や 1 次巻線で生じる電圧降下などを測定す る際に用いる. なお, Fig. 5 に示寸変圧器の 2 次側に繋が

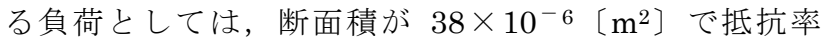
$\rho=1.72 \times 10^{-8}[\Omega \cdot \mathrm{m}]$ の電線を用い全長 $=1.54[\mathrm{~m}]$ の並 行 2 芯としている. なお，ケーブルの抵抗 $r_{1}$ は, $20\left[{ }^{\circ} \mathrm{C}\right]$ で $1.39 〔 \mathrm{~m} \Omega]$ である.

変圧器を内蔵するインバータ電源の周波数を制御して溶 接電流を制御する際, 検討しなければならないのは, 変圧 器の 1 次巻線から見た溶接回路のインピーダンスと変圧器 の内部インピーダンスである.ここで, 変圧器の励磁アド ミタンス $Y_{0}$, 励磁コンダクタンス $g_{0}$, 励磁サセプタンス $b_{0}$ それぞれの 1 次電圧依存性と周波数依存性は, 鉄心が磁 気飽和を起こさない限り特別な問題とはならない. なお,

これらの詳細については文献"16)" に示している.

変圧器の内部インピーダンスは, 簡易型等価回路を用い た短絡試験から求める。

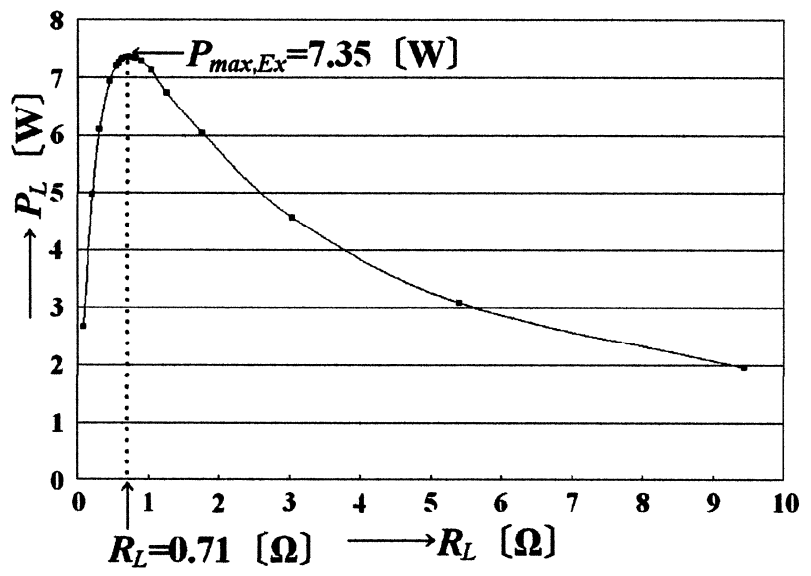

$\left.\left.\left.V_{\mathrm{S}}=4.647 〔 \mathrm{~V}\right\rfloor, f_{\mathrm{S}}=100 〔 \mathrm{~Hz}\right], r_{\mathrm{S}}=0.72 〔 \boldsymbol{\Omega}\right], x_{\mathrm{S}}=0[\boldsymbol{\Omega}]$, $L_{\mathrm{L}}=0\lceil\mathrm{H}]$

Fig. 3 Behavior of $P$ with varying $R_{\mathrm{L}}$ (square wave).

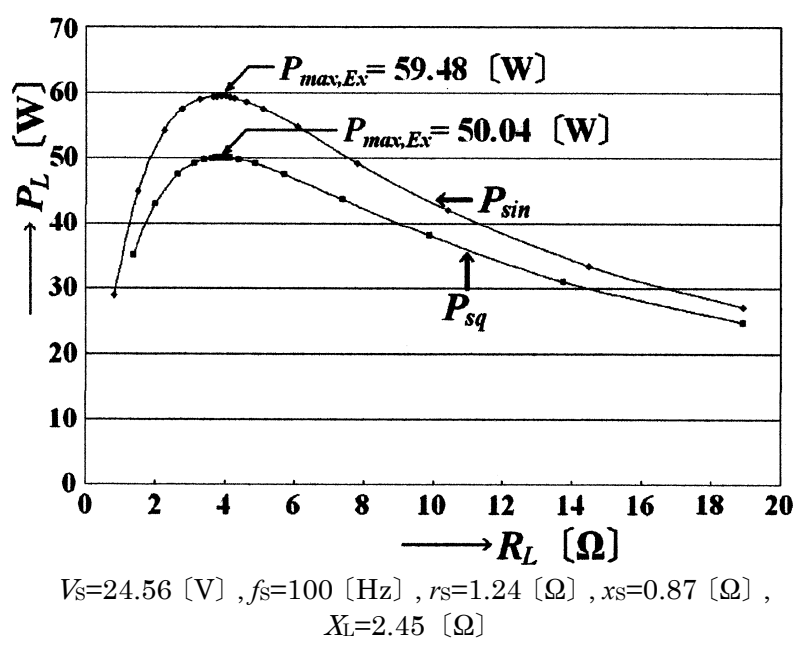

Fig. 4 Behavior of $P$ with varying $R_{\mathrm{L}}$.

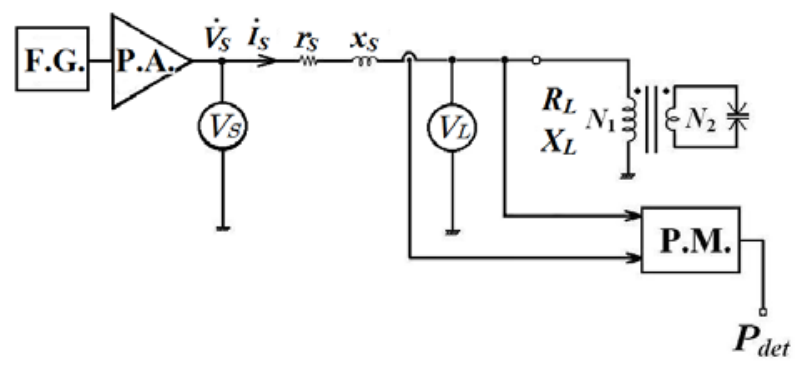

Fig. 5 Experimental circuit for impedance matching with transformer.

Table 1 Transformer used in experiment.

\begin{tabular}{|c|c|c|c|c|}
\hline$N_{1, \mathrm{p}}=N_{1, \mathrm{n}}$ & $N_{\text {sch }}$ & $N_{2}$ & $l_{\text {core }}$ & $S_{\text {core }}$ \\
\hline 40 turns & 10 turns & 1 turn & \multirow{3}{*}{$\begin{array}{c}0.609 \\
{[\mathrm{~m}]}\end{array}$} & \multirow{3}{*}{$\begin{array}{c}20 \times 10^{-4} \\
\lceil\mathrm{~m}]\end{array}$} \\
\hline $\begin{array}{c}\text { Coil size } \\
22 \\
\left\lceil\mathrm{~mm}^{2}\right\rceil\end{array}$ & $\begin{array}{c}\text { Coil size } \\
7.03 \times 10^{-2} \\
{\left[\mathrm{~mm}^{2}\right]}\end{array}$ & $\begin{array}{c}\text { Coil size } \\
\left.780 〔 \mathrm{~mm}^{2}\right\rceil\end{array}$ & & \\
\hline $\begin{array}{c}4.90[\mathrm{~m} \Omega] \\
\left(20\left[{ }^{\circ} \mathrm{C}\right]\right)\end{array}$ & $\begin{array}{l}1.44[\Omega] \\
\left(20\left[{ }^{\circ} \mathrm{C}\right]\right)\end{array}$ & $\begin{array}{l}9.67[\mu \Omega] \\
\left(20\left[{ }^{\circ} \mathrm{C}\right]\right)\end{array}$ & & \\
\hline
\end{tabular}




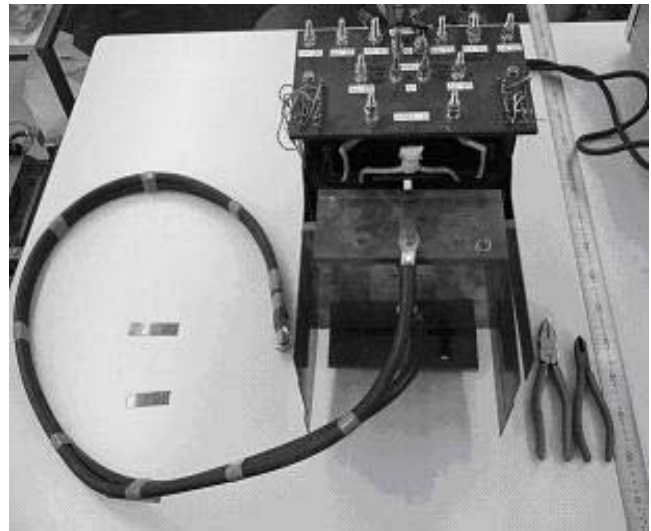

Fig. 6 Transformer used in experiment.

Fig. 7 は, 変圧器の励磁部を無視して短絡試験を行う際 の等価回路である ${ }^{21)}$. これより，(8)式から(11)式までの関 係が得られる. Fig. 6 の試作した変圧器の 1 次側に換算し た抵抗 $r_{\mathrm{S}}$ を(9)式より求めると $r_{\mathrm{S}}=20.37 〔 \mathrm{~m} \Omega 〕$ とな.

$$
\begin{aligned}
& \dot{Z}_{S}=\frac{\dot{V}_{1 S}}{\dot{I}_{1 S}} \cdots \\
& r_{S}=r_{1}+a^{2} r_{2} \\
& x_{S}=\sqrt{Z_{S}^{2}-r_{S}^{2}} \\
& l_{S}=\frac{x_{S}}{2 \pi f_{1 S}} \cdots
\end{aligned}
$$

Fig. 8 は, 変圧器の 2 次側を短絡し, 1 次短絡電流 $I_{1 \mathrm{~S}}$ を $5 ， 10 ， 15 ， 20 ， 25[\mathrm{~A}(\mathrm{rms})]$ とした場合の励磁電源周波 数 $f_{1 \mathrm{~S}}$ に対する 1 次側に換算したインダクタンス $l \mathrm{~s}$ の振舞 いである. $f_{1 \mathrm{~S}}$ が高くなるにつれて $l_{\mathrm{S}}$ が小さくなるのは, 1 次巻線から見た鉄心の等価透磁率 $\mu_{\mathrm{eq}}$ が高周波領域で小さ くなるからである ${ }^{20)}$ 。つまり，成層した鉄心内で形成され た一種の短絡回路には, 磁束の時間変化に基づく電流が流 れ，同様に成層鉄心を構成する各電磁鋼板内にも渦電流が 流れる. これらの電流によって変圧器鉄心磁束の時間変化 が妨げられる結果と考えている。なお， $I_{1 \mathrm{~S}}$ を～ 525

$[\mathrm{A}(\mathrm{rms})] に し た$ 場合の電流依存性は, 小さいとみて良い.

Fig. 9 は， fis を $10[\mathrm{~Hz}] \sim 1[\mathrm{kHz}]$ とした場合の $I_{1 \mathrm{~S}}$ に対する $l_{\mathrm{S}}$ の振舞いである. $l_{\mathrm{S}}$ の電流依存性が小さいのは, 短絡試験であることから，鉄心の磁束密度が小さいことを 示している. $I_{1 \mathrm{~S}}$ の増加に対して $l_{\mathrm{S}}$ が若干増加しているのは, 周波数制御形インバータ電源としては好都合である ${ }^{20)}$.

ここで，Fig. 8, Fig. 9 は，文献"20）"に示す Fig. 4, Fig. 5 のそれぞれを引用している.

Fig. 10 は, Fig. 6 に示すように変圧器の 2 次側に繋いだ 並行 2 芯ケーブルのインダクタンス $l_{1}$ の周波数特性を示し ている. 電源周波数 $f_{\mathrm{S}}$ が高くなるにつれてケーブル導体内 の渦電流の影響で $l_{1}$ は小さくなっている. しかしながら， $l_{1}$ は $[\mu \mathrm{H}]$ 程度以下であることと, 検討するインバータ電 源の周波数は $10 〔 \mathrm{kHz} 〕$ 以下を考えているので大きな問題 とはならない. Fig. 6 に示寸変圧器の 1 次巻線端子から見 た $(2)$ 式の $R_{\mathrm{L}}$ を求めると, 変圧器の 2 次側に繋いだケーブ ルの抵抗 $r 1$ は $1.39[\mathrm{~m} \Omega]$, また, Table 1 に示す $r_{1}=4.90$ $[\mathrm{m} \Omega], a=40$ であることから(12)式となる。また， $X_{\mathrm{L}}$ は, (13)式から求められる.

$$
\begin{aligned}
& R_{L}=r_{1}+a^{2}\left(r_{2}+r_{l}\right)=2.24 \\
& X_{L}=2 \pi f_{1 \mathrm{~S}}\left\{l_{1}+a^{2}\left(l_{2}+l_{l}\right)\right\}
\end{aligned}
$$

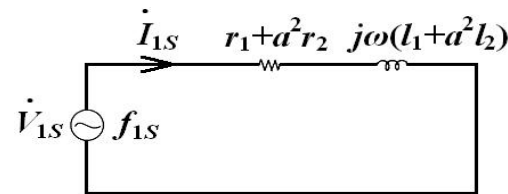

$\dot{V}_{1 \mathrm{~s}}$ : Primary short circuit voltage, $f_{1 \mathrm{~S}}$ : Power supply frequency, $\dot{I}_{1 \mathrm{~s}}$ : Primary short circuit current, $r_{1}, r_{2}$ : Primary and secondary winding resistance of the transformer, $a=N_{1} / N_{2}$ : Turn ratio of the transformer, $\omega=2 \pi f_{1 \mathrm{~S}}$ : Angular frequency, $l_{1}, l_{2}$ : Primary and secondary winding leakage inductance of the transformer.

Fig. 7 Equivalent circuit for short-circuit test.

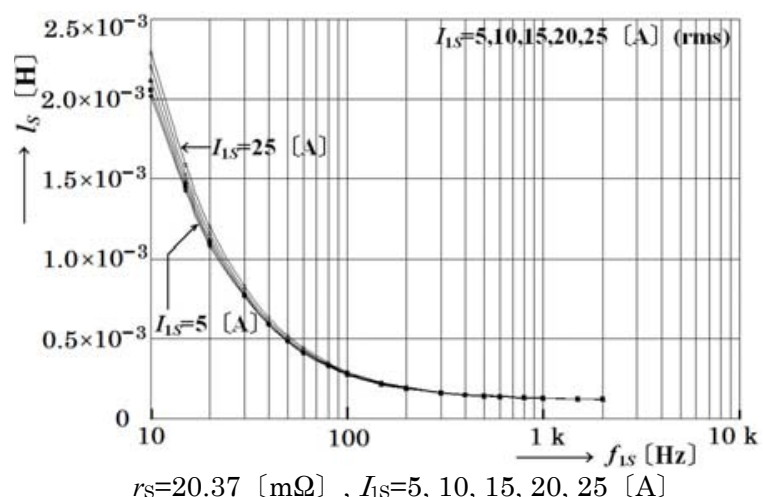

Fig. 8 Behavior of $l_{\mathrm{S}}$ with varying excitation frequency $f_{1 \mathrm{~S}}$.

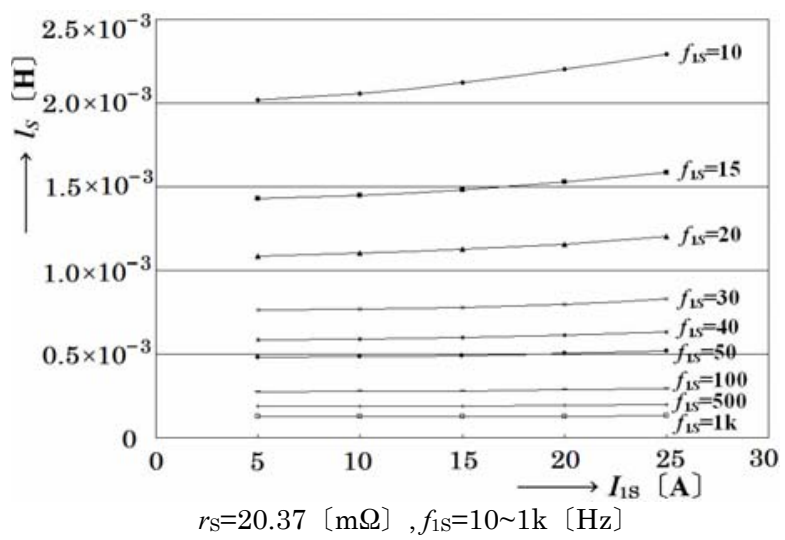

Fig. 9 Behavior of $l_{\mathrm{S}}$ with varying primary short-circuit current $I_{1 \text { s. }}$.

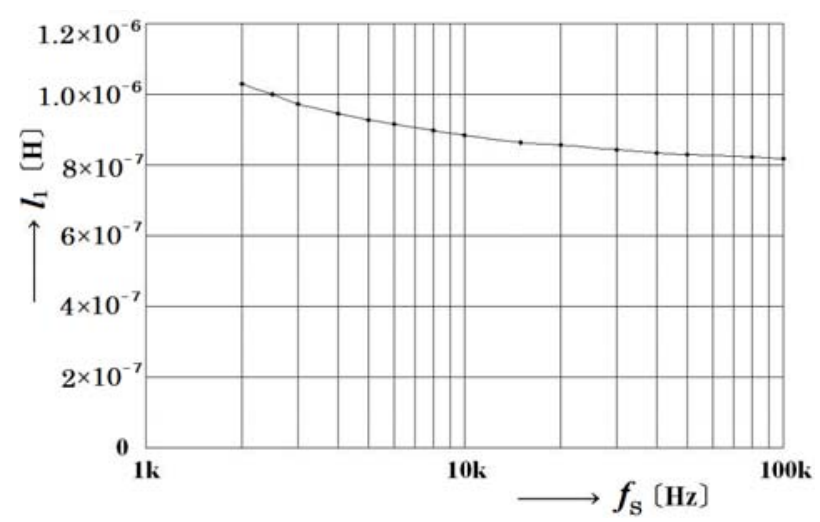

Fig. 10 Characteristics of $l_{1}$ for frequency $f_{\mathrm{s}}$. 
なお $X_{\mathrm{L}}$ は，Fig. 8，9，10 に示すようにls と $l 1$ が，とも に周波数と電流に依存することから簡単には求まらない.

したがって, 変圧器を内蔵した電源と負荷とのインピー ダンスマッチングについて検討するのは難しいといえる.

そこで, 電源周波数を $100 〔 \mathrm{~Hz} 〕$ とし, Fig. 8 より $l_{\mathrm{S}}=0.3$ $[\mathrm{mH}], \quad l 1$ を $1.1[\mu \mathrm{H}]$ とすると 1 次側に換算したイン ダクタンス成分は

$l_{s}+a^{2} l_{1}=0.3 \times 10^{-3}+40^{2} \times 1.1 \times 10^{-6}=2.06 \times 10^{-3}$

となり，(2)式は，(14)式となる.

$$
\dot{Z}_{L}=R_{L}+j X_{L}=2.24+j 200 \pi \times 2.06 \times 10^{-3}
$$$$
=2.24+j 1.29
$$

Fig. 11 は, Fig. 5 の実験回路で電源周波数 $f_{\mathrm{S}}$ を変化させ た場合の変圧器 1 次巻線に供給される電力 $P_{1 \mathrm{~L}}$ の振舞いを 測定したものである。図に示す $P_{\sin }$ は電源が正弦波の場合 で， $P_{\mathrm{sq}}$ は矩形波の場合である.なお，Fig. 11 の下部には， 実験条件 $V_{\mathrm{S}}, r_{\mathrm{s}}, R_{\mathrm{L}}$ を示している. 正弦波の場合， $P_{\mathrm{sin}}$ は $f_{S}=47.0[\mathrm{~Hz}]$ 近傍で最大となり, この場合の(14)式は, Fig. 9 より, $l_{\mathrm{S}}=0.5[\mathrm{mH}]$, Fig. 10 より $l_{1}$ を $1.1[\mu \mathrm{H}]$ とする と次式となる.

$$
\dot{Z}_{L}=2.24+j 0.67\lceil\Omega]
$$

矩形波の場合 $P_{\mathrm{sq}}$ は, $f_{\mathrm{S}}=37.5 〔 \mathrm{~Hz} 〕$ 近傍で最大となり, 正弦波よりも低い周波数で最大となっている。この理由は, 高調波成分に基づくリアクタンス成分の増加である.

Fig. 11 の結果は，正弦波，矩形波いずれの場合でも， 1 次巻線に供給される電力を最大とする周波数が存在するこ とを示している。

\section{3. 周波数制御形インバータ電源と負荷との インピーダンスマッチング}

ここでは，実際の周波数制御形インバータ電源を用いた 場合のインピーダンスマッチングはどうなるかを確認する。

Fig. 12 は, 検討する周波数制御形インバータ電源である 1) 3). この電源は，小規模の商用電源で $10[\mathrm{kA} 〕$ 以上の溶 接電流 $i_{\mathrm{W}}$ を得るために蓄電池 $\mathrm{B}$ を用いている。つまり, 非 溶接時に蓄電池に充電しておき, 溶接時には, 商用電源と 蓄電池の両方から溶接に必要な電力を供給する方式であ る。また，このインバータ電源は，産業界に広く普及して いる PWM 方式と異なり， $\mathrm{S}_{1}$ と $\mathrm{S}_{2}$ を交互に on-off する極 めて簡単な方式となっている.

Fig. 13 は, Fig. 12 に示す周波数制御形インバータ電源 に, Fig. 5 に示す変圧器の 2 次側を短絡して繋いだ場合の 動作波形例である.ここでは蓄電池電圧 $V_{\mathrm{B}}=36[\mathrm{~V}]$ とし，

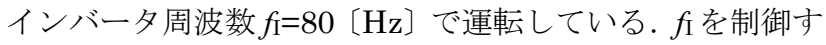

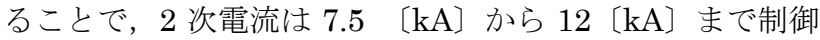
できる ${ }^{19)}$. 1 次巻線 $N_{1, \mathrm{p}}, N_{1, \mathrm{n}}$ の電圧 $v_{1, \mathrm{p}}, v_{1, \mathrm{n}}$ の振舞は, 負 から正に対し $2[\mathrm{~V} / \mu \mathrm{s}]$, 正から負に対しては IGBT の on 特性で定まり, 約 $870 〔 \mathrm{~V} / \mu \mathrm{s}]$ 程度である。これら on, off に要する時間は, Fig. 1 と Fig. 5 で示した $60[\mathrm{~V} / \mu \mathrm{s} 〕$ のス ルーレートと異なるが, インバータの動作周波数を考え理 想的に on, off していると考える.

電源と負荷とのインピーダンスマッチングの整合性は, (4)式で判断できる. 例えば, 電源に電圧源を用いて $R, L$ の 直列回路で $R$ が変化する負荷に電力を供給する場合を考え ると, 周知のように負荷抵抗と負荷のリアクタンス成分の 大きさとが等しい時に負荷電力は最大となる.したがって, 負荷電力を最大とする電源周波数が存在することになる.

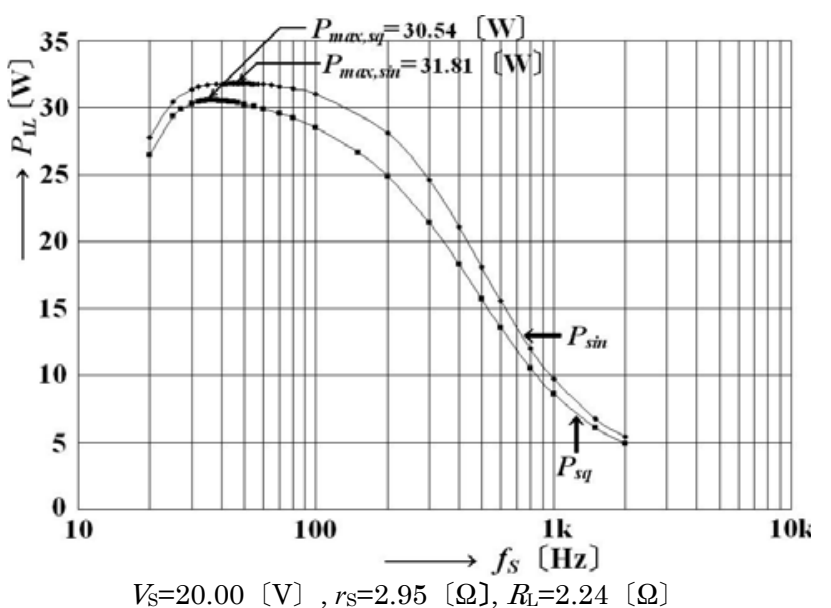

Fig. 11 Behavior of $P_{1 L}$ with varying excitation frequency $f \mathrm{~s}$.

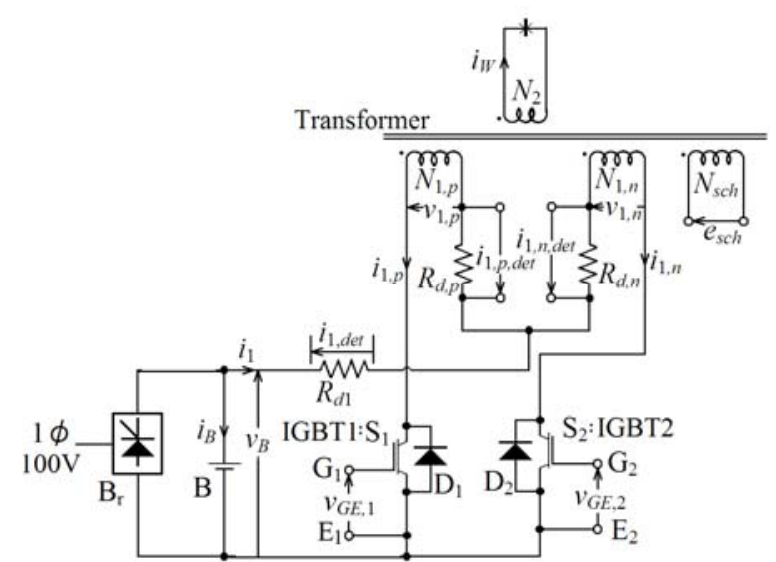

Br: Thyristor bridge, B: Battery $12 \times 3\lfloor\mathrm{~V}\rfloor, i_{\mathrm{B}}$ : Battery current, $v_{\mathrm{B}}$ : Battery voltage, $i_{1}$ : Primary current of the transformer, $i_{\mathrm{W}}$ : Secondary current, $R_{\mathrm{d} 1}$ : Detecting resistance of $i_{1}, i_{1, \text { det }}:$ Detecting signal of $i_{1}, \mathrm{~S}_{1}, \mathrm{~S}_{2}$ : IGBT,

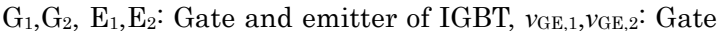
voltage of IGBT, $\mathrm{D}_{1}, \mathrm{D}_{2}$ : Free wheeling diode, $v_{1, \mathrm{p}}, v_{1, \mathrm{n}}$ : Primary winding $N_{1, \mathrm{p}}, N_{1, \mathrm{n}}$ voltage, $i_{1, \mathrm{p}}, i_{1, \mathrm{n}}$ : Primary winding current, $R_{\mathrm{d}, \mathrm{p}}, R_{\mathrm{d}, \mathrm{n}}$ : Detecting resistance of $i_{1, \mathrm{p}}$, $i_{1, \mathrm{n}}, i_{1, \mathrm{p}, \mathrm{det},}, i_{1, \mathrm{n}, \mathrm{det}}:$ Detecting signal of $i_{1, \mathrm{p}}, i_{1, \mathrm{n}}, N_{\mathrm{sch}}:$ Search coil, $e_{\text {sch }}$ : Search coil voltage, $N_{2}$ : Secondary winding

Fig. 12 Frequency-controlled inverter power supply.

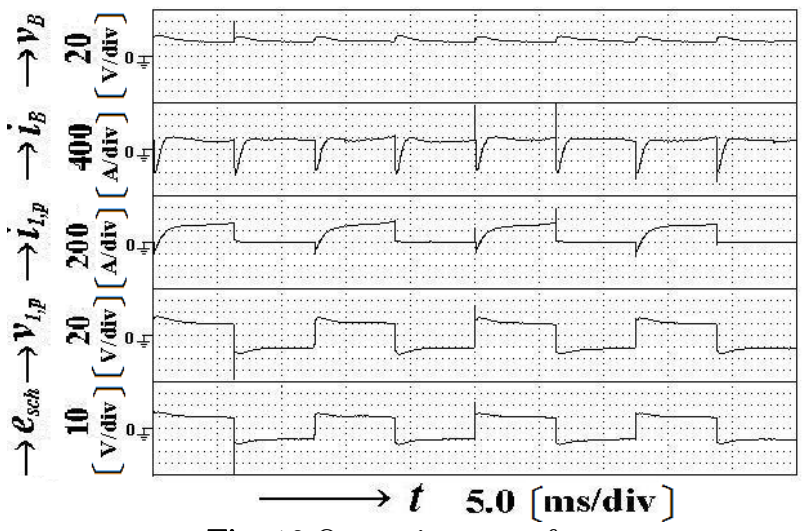

Fig. 13 Operating waveforms. 
ところが，上述したように， $X_{\mathrm{L}}$ は $l \mathrm{~s}$ と $l \mathrm{l}$ がともに周波 数と電流の大きさに依存することから簡単には定まらない.

また，インバーに用いる蓄電池 B の内部抵抗, IGBT と IGBT に並列接続する還流ダイオードの内部抵抗の電流依 存性までを考えると，このマッチングの問題は極めて難し くなってしまう。 そこで, 変圧器の 1 次巻線端子における 力率 $\cos \varphi_{1 \mathrm{~L}}$ に着目する．仮に，電源に繋がる負荷が抵抗成 分のみであれば，力率は周波数に依存しなくなり，誘導成 分が支配的であれば，インバータ周波数に反比例して力率 は悪くなる，そこで，最大力率がインバータ周波数に依存 して定まれば, 最大力率で負荷に電力を供給することがで きることになる.

Fig. 14 は, Fig. 12 に示す電源の変圧器の 2 次側に負荷 として 2.3 節同様， $20\left[{ }^{\circ} \mathrm{C}\right]$ で $1.39 \llbracket \mathrm{m} \Omega 〕$ のケーブルを 繋ぎインバータ周波数 $\mathrm{f}_{\mathrm{I}}$ を変化させた場合の変圧器 1 次巻 線における力率 $\cos \varphi_{1 \mathrm{~L}}$ の振舞いを示したものである. Fig. 14 の結果は, 力率を最大とするインバータ周波数が存在す ることを示している. なお，Fig. 14 に示す $N_{1, \mathrm{P}}=35,40$, 45 は, Fig. 5 に示寸変圧器 1 次巻線の巻数である. $N_{1}=$ $N_{1, \mathrm{P}}=N_{1, \mathrm{n}}=40$ の場合, インバータ周波数 $\mathrm{f} \mathrm{i}$ は $90.1[\mathrm{~Hz}]$ で力率が最大となっている.

Table 2 は, 各 $N_{1}$ に対する最大力率を与えるインバータ 周波数などを䌂めたものである. 1 次巻数 $N_{1}$ が増えるにし たがって，最大力率を与える周波数 $f_{\mathrm{I}}$ が低くなるのは，変 圧器の漏れインダクタンスが巻数の増加に伴って大きくな るからである。

Fig.14に示すインバータ周波数に対する力率の振舞に対 して, 変圧器の 1 次巻線の片方 $N_{1, \mathrm{p}}$ に供給される電力 $P_{1 L}$ はどのようになるかを確認したのが Fig.15 である. なお,

Fig. 15 に示す $P_{1 L}$ は, 仮に $N_{1, \mathrm{p}}$ と $N_{1, \mathrm{n}}$ との対称性が得られ ていれば $2 P_{1 \mathrm{~L}}$ の電力が変圧器に供給されていることにな る. Fig. 15 の結果は、Fig. 5 の実験回路を用いた場合と異 なり， $P_{1 \mathrm{~L}}$ を最大とする周波数 $f_{1, \max }$ は存在せず，単に周波 数を低くした方が $P_{1 \mathrm{~L}}$ は大きくなっている.この原因は， 負荷インピーダンスのリアクタンス成分が電源周波数に依 存するからである。また，マッチングが得られないのは， 変圧器の 1 次巻線に繋がる電源のインピーダンスが極めて 小さかったからではないかと考えている。つまり，電源側 の等価インピーダンスは, Fig. 12 に示す電流検出抵抗であ る $R_{\mathrm{d} 1}$ と $R_{\mathrm{d}, \mathrm{p}}$ の抵抗值，蓄電池の内部抵抗と IGBT，還流 ダイオードの各内部抵抗が小さいからであると考えている しかしながら， $f_{\mathrm{I}}$ を制御することにより， $P_{1 \mathrm{~L}}$ の制御が可能 であることが確認できる. 周知のように， $f_{\mathrm{I}}$ の最小周波数 は, インバータに用いる変圧器の磁気飽和で制限される.

\section{4. インピーダンスマッチングに対する考察とまとめ}

本論文では，インバータ電源と負荷インピーダンスが 1 $[\mathrm{m} \Omega]$ 以下を想定したスポット溶接電力の振舞について検 討し, 次の(1), (2)を実験的に確認して(3)以降の結果を得た. （1）電源と負荷が共に抵抗成分のみであれば，正弦波，矩 形波いずれの場合も，電源の内部抵抗と負荷抵抗の大き さが等しい時に負荷電力は最大になる.

（2）電源と負荷とが共に抵抗と誘導成分を有する場合に は，正弦波，矩形波いずれの場合でも負荷電力を最大と する負荷抵抗が存在する。このことは，自明とはいえ最 大電力伝送定理を確認したことに繋がると考えている。

(3) 変圧器を内蔵する電子回路で構成するインバータ電源 を用いた場合には，正弦波，矩形波いずれの場合でも，

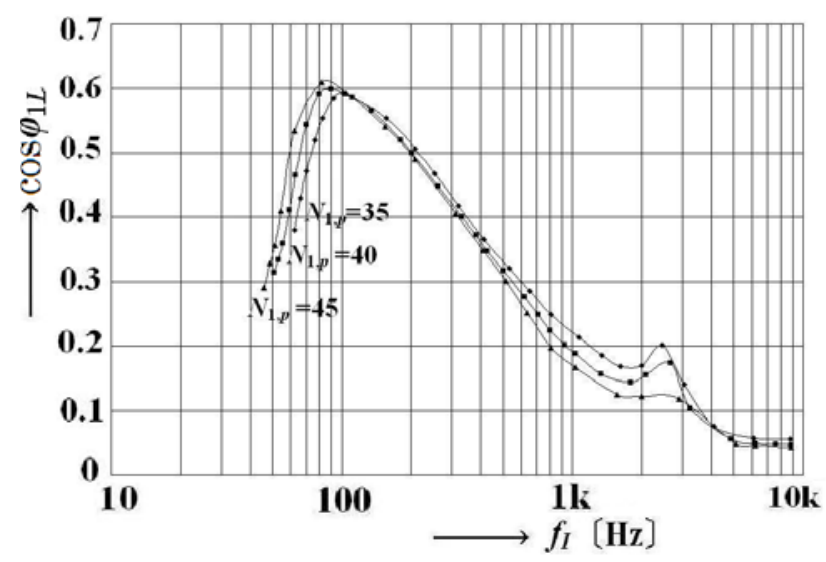

Fig. 14 Behavior of $\cos \varphi_{1 \mathrm{~L}}$ with varying inverter frequency $f$.

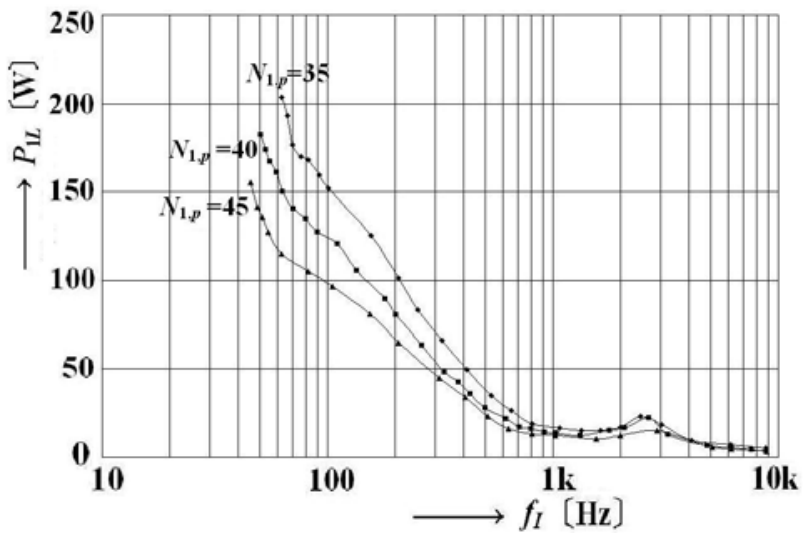

Fig. 15 Behavior of $P_{1 L}$ with varying inverter frequency $f \mathrm{i}$

Table 2 Relationship between inverter frequency and maximum power factor for $N_{1}$.

\begin{tabular}{|c|c|c|c|c|}
\hline $\begin{array}{c}N_{1} \\
\text { [turns } 〕\end{array}$ & $\begin{array}{c}f_{\mathrm{I}} \\
{[\mathrm{Hz}]}\end{array}$ & $\begin{array}{c}V_{1} \\
{[\mathrm{~V}(\mathrm{rms})]}\end{array}$ & $\begin{array}{c}I_{1} \\
{[\mathrm{~A}(\mathrm{rms})}\end{array}$ & $\cos \varphi 1 \mathrm{~L}$ \\
\hline 35 & 101.1 & 27.77 & 9.23 & 0.59 \\
\hline 40 & 90.1 & 27.82 & 7.64 & 0.60 \\
\hline 45 & 82.0 & 27.86 & 6.18 & 0.61 \\
\hline
\end{tabular}

変圧器の 1 次巻線に供給する電力が最大となる周波数の 存在することを確認した.

（4）具体的に巻数比の大きい変圧器を内蔵する IGBT を用 いて構成した周波数制御形インバータ電源を運転した場 合, 変圧器の 1 次巻線における力率が最大となるインバー 夕周波数の存在することを確認した.

(5) 変圧器の 1 次側に換算したインダクタンス $l \mathrm{~s}$ は, イン バータ周波数と電流の大きさに依存すること，更にはイ ンバーに用いる蓄電池 B の内部抵抗，IGBT と IGBT に 並列接続する還流ダイオードの内部抵抗の電流依存性ま でを考えるとこのインピーダンスマッチングの詳細は， 極めて難しくなってしまうと言える.

（6）巻数比の大きい変圧器を内蔵する周波数制御形インバ 一タ電源でスポット溶接電力の制御を行う際, 最大力率 で運転できることを確認した。

(7) スポット溶接部に供給する熱量は，溶接部で消費され る電力の時間積分であることから，最大電力で運転する場 
合の溶接時間との関係については，今後の課題である.

そして, 溶接部抵抗の時間変化も考慮する必要があると考 えている.

以上の検討結果から, 巻数比の大きい変圧器を内蔵する インバータ電源と $1 〔 \mathrm{~m} \Omega 〕$ 以下を想定したスポット溶接電 力の振舞と溶接負荷とのインピーダンスマッチングに対す る一つの指針を得ることができたと考えている.

\section{References}

1) Y. Takasaki and T. Sonoda: IEEE Trans. Magn., 41, pp.4054-4056 (2005).

2) T. Asada, T. Munesada, T. Sonoda, and Y. Takasaki: Int. Conf. on Elec. Engi. 2009, Shenyang, China, Conf. Rec., I9FP0511, 07, Jul. (2009).

3) T. Munesada, Y. Takasaki, and T. Sonoda: $16^{\text {th }}$ Int. Conf. on Elec. Engi. July 11-14, 2010 Busan Korea, Conf. Rec., CIT-01 (2010)

4) M. Kabasawa: Journal of the Japan Welding Society, 68, pp.74-78 (1999) (in Japanese).

5) M. Kondo: Journal of the Japan Welding Society, 79, 8, pp.750-759 (2010) (in Japanese).

6) Y. Turuhara: Toyota Body, D\&M News Report, 9, 588, pp.14-15 (2003) (in Japanese).

7) T. Yoshida: Journal of the Japan Welding Society, 79, 5, pp.448-449 (2010) (in Japanese).

8) T. Sonoda, Y. Takasaki, and K. Amane, A. Wada: Int. Conf. on Elec. Engi. 2001 Conf. Rec., pp.1792-1795 ( 2001).

9) S. Fujii, T. Sonoda, and Y. Takasaki: JIEE Research Canf Rec., MAG-03-161, pp.5-10 (2003) (in Japanese).
10) Y. Takasaki, T. Sonoda, and S. Fujii: T.IEE Japan, IA, 125, 5, pp.420-425 (2005) (in Japanese).

11) T. Noguchi, K. Nishiyama, K. Ishida, Y. Asai, and T. Matsubara : IEEJ Trans. IA, 126, 1, pp.48-55 (2006) (in Japanese).

12) Y. Onozawa, M. Otsuki, N. Iwamuro, S. Miyashita, T Miyasaka, Y. Seki, and T. Matsumoto: IEEE Trans. IA, 43, 2, pp. 513-519 (2007).

13) H. Ninomiya, S. Umekawa, S. Wakiyama, and K. Nishitani: Toshiba Review, 65, 1, pp.15-18 (2010) (in Japanese).

14) T. Shinohe: Toshiba Review, 59, 2, pp.49-53 (2004) (in Japanese).

15) M. Niwayama, S. Kazama, C. Kudo, and M. Kitabatake: Panasonic Technical Journal, 57, 1, pp.9-14 (2011) (in Japanese).

16) T. Asada, T. Sonoda, and Y. Takasaki: JIEE Research Canf. Rec., MAG-08-9, pp.43-48 (2008) (in Japanese).

17) S. Takeyama: Denjikigaku gensyouriron (in Japanese), pp. 218-219, Maruzen (1982).

18) S. Takagi: Kaiseki gairon (in Japanese), pp. 60-71, Iwanami shyoten (1959).

19) T. Sonoda, T. Asada, and Y. Takasaki: Int. Conf. on Elec. Engi. 2007, Hong Kong, Conf. Rec., ICEE-308, 09, Jul. (2007).

20) Y. Takasaki, and T. Sonoda: J. Magn. Soc. Jpn., 36, pp.13-19 (2012)

21) S. Miyairi: Daigaku Kougi Saissin Denki-kikigaku (in Japanese), pp.94-95 (Maruzen, 1979).

2011年10月01日受理，2011年12月04日再受理，2012年1月18日採録 